\title{
Entertainment Cost Efficiency Analysis With Data Envelopment Analysis (Dea) And Fuzzy Logic (Flp \& C-Iowa) Approach To Sales Level
}

\section{Analisa Efisiensi Biaya Entertainment Dengan Pendekatan Data Envelopment Analysis (Dea) Dan Fuzzy Logic (Flp \& C-Iowa) Terhadap Tingkat Penjualan}

\author{
Dwi Kakung Saputro ${ }^{1}$, Tedjo Sukmono ${ }^{* 2}$ \\ \{dwikakungsaputro@gmail.com ${ }^{1}$, thedjoss@ umsida.ac.id² $\}$
}

Program Studi Teknik Industri, Fakultas Sains dan Teknologi, Universitas Muhammadiyah Sidoarjo

\begin{abstract}
It caused some problems regarding to calculation and measurement of costs which is issued for the level of efficiency desired by the company, namely PT. LLL Surabaya. From the results of measurements and analysis, it shows that system has objective value in "efficient" category. Therefore, the ranking results of regional operating system (DMU3) are the most optimal in terms of sales capacity, which is Rp. 11,745,050,779. It is caused by the impact of providing these costs. Based on the decision-making preferences related to the entertainment costing system, (CI) value is 0.18 for (P1) and 0.03 for (P2). It means that marketing department has more preference for entertainment costing system should be given constantly with the aim that total sales capacity can continue to increase.
\end{abstract}

Keywords - Consistency Index (CI); DEA; DMU; Fuzzy Logic; Objective value

\begin{abstract}
Abstrak. Dimana kondisi awal sistem pemberian biaya entertainment dilakukan secara berganti-ganti, sehingga menimbulkan permasalahan tentang perhitungan dan pengukuran biaya yang dikeluarkan atas tingkat efisiensi yang diinginkan pihak perusahaan yaitu PT. LLL Surabaya. Dalam pemecahan masalahnya digunakan metode (DEA) serta Fuzzy. Dari hasil pengukuran dan analisis diketahui jika sistem yang ada memiliki nilai objective value dalam kategori "efisien". Kemudian diperoleh juga hasil perankingan dengan sistem operasi wilayah (DMU3) menjadi yang paling optimal dalam hal kapasitas penjualan sebesar Rp.11.745.050.779 tentunya atas impact pemberian biaya tersebut. Berdasarkan preferensi pengambil keputusan terkait sistem pemberian biaya entertainment mempunyai besaran nilai (CI) 0,18 (P1) serta 0,03 untuk (P2). Artinya pihak marketing lebih memiliki preferensi untuk sistem pemberian biaya entertainment agar diberikan secara konstan dengan tujuan terus diharapkannya kapasitas total penjualan dapat meningkat.
\end{abstract}

Kata Kunci - Consistency Index (CI); DEA; DMU; Fuzzy Logic; Objective value

\section{Pendahuluan}

Kaitan perusahaan dengan bahasan tema efisiensi sekarang ini memang terdengar akrab secara umum. Hal ini didasarkan karena setiap perusahaan memang semestinya ingin mendapatkan hasil yang maksimal dengan input yang ada dan tepat pada sasarannya. Konsep efisiensi terkait dengan perbandingan output dengan input digunakan untuk mengukur kinerja suatu unit kegiatan ekonomi untuk mencapai prestasi yang sebesar-besarnya dengan menggunakan kemungkinan-kemungkinan yang tersedia [1].

PT LLL Surabaya merupakan perusahaan distributor yang bergerak dalam bidang penyediaan barang dan jasa pemasangan barang berupa Office Equipment (OE) serta Racking System. Dari transaksi penjualan yang dilakukan oleh PT LLL muncul yaitu yang namanya biaya entertainment, biaya ini diberikan saat semua transaksi terselesaikan mulai dari proses penawaran sampai pembayaran atas order yang telah disepakati. Untuk saat ini biaya entertainment dihitung secara per satuan penjualan. Dimana dalam kurun waktu 2 tahun sistem Pemberian biaya yang diterapkan selalu berubah yang mengakibatkan kebingungan atas perhitungan biaya entertainment yang mestinya diberikan ke pihak marketing PT LLL Surabaya. Biaya entertainment sendiri merupakan bentuk usaha dari pihak perusahaan untuk menjaga dan menfasilitasi selama transaksi berlangsung sehingga dengan adanya hal tersebut proses transaksi menjadi lebih dirasa perusahaan mestinya memberikan kesan dan impact yang baik terhadap para customernya.

Ada beberapa data mengenai total pembelian, penjualan, dan biaya entertainment yang dimiliki oleh PT LLL Surabaya pada periode tahun 2017 sampai dengan 2018.

Tabel 1. Rekapitulasi Pembelian, Penjualan, dan Biaya Entertainment PT LLL

\begin{tabular}{cccc}
\hline Tahun & Pembelian & Penjualan & $\begin{array}{c}\text { Biaya } \\
\text { Entertainment }\end{array}$ \\
\hline 2017 & 16.606 .382 .929 & 23.711 .365 .812 & 1.421 .858 .000 \\
\hline
\end{tabular}


Procedia of Engineering and Life Science Vol. 1. No. 1 March 2021

Seminar Nasional \& Call Paper Fakultas Sains dan Teknologi (SENASAINS $1^{\text {st) }}$

Universitas Muhammadiyah Sidoarjo

\begin{tabular}{cccc}
2018 & 19.565 .535 .444 & 22.578 .469 .211 & 1.047 .578 .600 \\
\hline Sumber Data & Purchasing Report & Sales Report & Account Report
\end{tabular}

Berdasarkan data tabel 1. diharapkan dapat diketahui seberapa besar pengaruh pemberian biaya entertainment tersebut terhadap tingkat kapasitas penjualan PT LLL Surabaya.

\section{METODE}

\section{A. Data Envelopment Analysis (DEA)}

Data Envelopment Analysis (DEA) ini digunakan untuk menganalisa dari beberapa aktivitas sebuah unit kerja dalam suatu kelompok organisasi tertentu, dan unit kerja tersebut biasanya bisa diistilahkan sebagai Decision Making Unit (DMU) [2]. Decision Making Unit (DMU) merupakan suatu unit kerja yang memiliki persamaan dalam hal ciri serta karakteristik penerapannya dalam mewakili beberapa objek penelitian [2]. Terdapat 2 model pengukuran dalam metode Data Envelopment Analysis (DEA), yaitu model CCR dan BCC. Dimana model CCR proses pengukuran dan perhitungannya berdasarkan constan teturns to scale (CRS) yang akan menghasilkan suatu pola yang menunjukan apabila terdapat pertambahan nilai dari suatu input, maka nilai output yang dihasilkan juga akan mengalami peningkatan secara proporsional. Sedangkan untuk model BCC sendiri dalam berprosesnya model ini memakai varible returns to scale (VRS) yang kemudian akan didapat sebuah gambaran mengenai pertambahan nilai input akan mempengaruhi nilai output dengan proporsi yang bervariasi tergantung dengan ukuran dari suatu DMU [3]. Atas dasar hal tersebut model CCR terpilih menjadi alat untuk pengukuran kinerja sistem pemberian biaya entertainment. Adapun model dasar CCR dinotasikan berikut ini [2].

$$
\max h_{0}(u, v)=\frac{\sum_{r} U_{r} Y_{r o}}{\sum_{i} V_{i} X_{i o}}
$$

Subject to

$$
\begin{aligned}
& \frac{\sum_{r} U_{r} Y_{r j}}{\sum_{i} V_{i} X_{i j}} \leq 1 \text { for }=1, \ldots, \mathrm{n} \\
& U_{r}, V_{i} \geq 0 \text { for all } i \text { and } r
\end{aligned}
$$

Keterangan:

$$
\begin{array}{ll}
\mathrm{r} & =\text { jumlah } \text { output. } \\
\mathrm{i} & =\text { jumlah } \text { input. } \\
\mathrm{Ur} & =\text { output } \text { ke-r yang terbobot. } \\
\mathrm{Vi} & =\text { input ke-i yang terbobot. } \\
\mathrm{Yro} & \text { = jumlah } \text { output } \text { ke-r yang digunakan oleh DMU. } \\
\mathrm{Xio} & =\text { jumlah } \text { input } \text { ke-i yang digunakan oleh DMU. }
\end{array}
$$

Dalam persamaan 1 mempunyai solusi komulatif yang tak terhingga, sehingga diperlukannya formulasi menjadi dalam bentuk linier programming [4]. Sehingga diperoleh persamaan (2) berikut ini.

$$
\sum_{\mathrm{r}=1}^{\mathrm{t}} \mathrm{U}_{\mathrm{r}} \mathrm{Y}_{\mathrm{kr}}, \mathrm{k}=\text { DMU yang diteliti }
$$

Batas Kendala :

$$
\begin{gathered}
\sum_{\mathrm{i}=1}^{\mathrm{m}} \mathrm{V}_{\mathrm{i}} \mathrm{X}_{\mathrm{ki}}=1 \\
\sum_{\mathrm{r}-1}^{\mathrm{t}} \mathrm{U}_{\mathrm{r}} \mathrm{Y}_{\mathrm{jr}}-\sum_{\mathrm{i}=1}^{\mathrm{m}} \mathrm{V}_{\mathrm{i}} \mathrm{X}_{\mathrm{ji}} \leq 0 \\
\mathrm{j}=1,2 \ldots, \mathrm{n} \quad \mathrm{U}_{\mathrm{r}}, \mathrm{V}_{\mathrm{i}} \geq 0 ; \mathrm{r}=1,2, \ldots, \mathrm{t} ; \mathrm{i}=1,2, \ldots, \mathrm{m}
\end{gathered}
$$

Dengan rasio yang diperoleh maka tingkat efisiensi yang maksimal dari suatu DMU dibatasi dengan nilai antara 0 sampai 1. Dengan begitu nilai optimal dari efisiensi (nilai tujuan dari program linier) mendekati nilai $1(100 \%)$. Dari model CCR optimasi dapat diketahui tentang bobot input, selesih variabel yang digunakan dan bobot dari DMU itu sendiri [2]. 


\section{B. Fuzzy Linier Programming (FLP)}

Data Envelopment Analysis (DEA) ini digunakan untuk menganalisa dari beberapa aktivitas sebuah unit kerja dalam suatu kelompok organisasi tertentu, dan unit kerja tersebut biasanya bisa diistilahkan sebagai Decision Making Unit (DMU) [2]. Decision Making Unit (DMU) merupakan suatu unit kerja yang memiliki persamaan dalam hal ciri serta

Pada Fuzzy Linier Programing (FLP), suatu fungsi obyektif akan optimalkan sedemikian rupa dengan menggunakan aturan harus terkendali dengan batasan-batasan yang dinotasikan dengan menggunakan himpunan fuzzy dengan bertujuan mencari suatu nilai $\mathrm{z}$ dari fungsi yang telah digunakan [5]. Fungsi keanggotaan untuk model 'keputusan' himpunan fuzzy dapat dimodelkan sesuai dengan teori berikut ini.

$$
\mu_{\mathrm{D}}[\mathrm{x}]=\min _{\mathrm{i}}^{\min }\left\{\mu_{\mathrm{i}}\left[\mathrm{B}_{\mathrm{i}} \mathrm{x}\right]\right\}
$$

Harapannya untuk mendapatkan solusi terbaik yaitu suatu solusi dengan nilai keanggotaan yang paling besar, dengan demikian solusi sebenarnya adalah:

$$
\max _{x \geq 0} \mu_{D}\left[B_{x}\right]=\max _{x \geq 0} \min \left\{\mu_{i}\left[B_{i} x\right]\right\}
$$

Dari persamaan (3) terlihat bahwa $\mu_{\mathrm{i}}\left[\mathrm{B}_{\mathrm{i}} \mathrm{x}\right]=0$ jika batasan ke-i benar-benar dilanggar. Sebaliknya, $\mu_{\mathrm{i}}\left[\mathrm{B}_{\mathrm{i}} \mathrm{x}\right]=1$ jika batasan ke-i benar-benar dipatuhi (sama halnya dengan batasan bernilai tegas). Nilai $\mu_{\mathrm{i}}[\mathrm{Bx}]$ akan naik secara monton pada selang $[0,1]$, seperti persamaan (5).

$$
\mu_{i}\left[B_{i} x\right]=\left\{\begin{array}{cc}
1 ; & \text { jika } B_{i} x \leq d_{i} \\
\in[0,1] ; & \text { jika } d_{i}<B_{i} x \leq d_{i}+p_{i} \\
0 ; & \text { jika } B_{i} x>d_{i}+p_{i} \\
i=0,1,2, \ldots, m
\end{array}\right.
$$

Dengan Pi adalah toleransi interval yang diperbolehkan untuk melakukan pelanggaran baik pada fungsi obyektif maupun batasan. Dengan mensubtitusikan persamaan yang ada, maka akan diperoleh persamaan (6).

$$
\max _{x \geq 0} \mu_{D}\left[B_{x}\right]=\max _{x \geq 0 \quad i n}\left\{\mu_{i}\left[1-\frac{B_{i} x-d_{i}}{P_{i}}\right]\right\}
$$

1)

berupa nomor yang diikuti tanda tutup kurung, misalnya , diberikan di belakang nama penulis (lihat contoh). Jika semua penulis berasal dari satu afiliasi, tanda ini tidak perlu diberikan.

\section{Consistency Induced Ordered Weight Averaging Programming (C-IOWA)}

Alat agregasi yang digunakan dengan mempertimbangkan format preferensi yang diberikan oleh para pengambil keputusan dalam preferensinya salah satunya dengan Consistency Induced Ordered Weighted Averaging (C-IOWA) [6]. C-IOWA ini menjelaskan mengenai pemakaian derajat kepentingan dari setiap pemilik pengambil keputusan dengan relasi preferensi fuzzy. Pemilihan operator agregasi ini didasari oleh setiap pengambil keputusan yang mempunyai derajat kepentingan yang sama atas permasalahan yang ada, sehingga nilai indeks konsistensi dapat diketahui dengan cara menganalisa relasi preferensi fuzzy yang diberikan oleh setiap pengambil keputusan.

Untuk membentuk relasi preferensi fuzzy yang konsisten $\left(\tilde{\mathrm{P}}^{\wedge} \mathrm{k}\right)$ dari relasi preferensi fuzzy yang tidak konsisten $\left(\mathrm{P}^{\wedge} \mathrm{k}\right)$, dapat dilakukan dengan menggunakan persamaan (7) [6].

$$
\widehat{P}_{i j}=\left\{\begin{array}{cc}
P_{i j} ; & i \leq j \leq i+1 \\
\left(P_{i j}+P_{i+1 i+2}+\cdots+P_{j-i j}\right)+\frac{(i+1)-j}{2} ; & j>i+1 \\
1-P_{i j} & j<i
\end{array}\right.
$$

Dengan catatan bahwa matrik $\mathrm{P}^{\wedge}$ tidak hanya berada pada kisaran $[0,1]$, tapi juga terletak pada $[\mathrm{a}, 1+\mathrm{a}]$. Oleh sebab itu digunakan persamaan (8) untuk mengetahui hasil nilai preferensi fuzzy yang konsisten $\left(\mathrm{P}^{\wedge} \wedge \mathrm{k}\right)[6]$.

$$
f(x)=\frac{1}{1+2 a}(x)+\frac{a}{1+2 a}=\frac{x+a}{1+2 a}
$$

Kemudian untuk mengetahui jarak $\left(\mathrm{P}^{\mathrm{k}}\right)$ dan $\left(\widetilde{\mathrm{P}}^{\mathrm{k}}\right)$ bisa digunakan persamaan $(9)$ untuk mengetahui suatu ukuran kosistensi dari matrik $\left(\mathrm{P}^{\mathrm{k}}\right)[6]$. 


$$
C I^{k}=d\left(P^{k}, \widetilde{P}^{k}\right)=\sqrt{\sum_{i=1}^{n} \sum_{j=1}^{n}\left(P_{i j}^{k}-\widetilde{P}_{i j}^{k}\right)^{2}}
$$

Jika hasil 1-CI ${ }^{\mathrm{k}}$ nilainya mendekati nilai 1 , maka hal tersebut mengindikasikan bahwa informasi yang diberikan oleh pengambil keputusan lebih konsisten.

Dengan metode fuzzy Logic (FLP \& C-IOWA) akan diketahui maksimisasi dari setiap DMU yang telah dilakukan pengukuran denga metode DEA. Harapan yang diinginkan dari perhitungan menggunakan FLP ini yaitu mengetahui tingkat penjualan pada setiap kali biaya entertainment diberikan. Hasil dari perhitungan FLP akan menjadi salah satu hal yang berpengaruh terhadap konsistensi dari setiap pengambil keputusan atas preferensinya untuk melakukan pemberian biaya entertainment. Sebab itu akan dilakukan pula perhitungan C- IOWA menggunakan persamaan (7) sampai dengan (9).

\section{Tahapan Anlisis}

Uraian kegiatan pada penelitian ini, meliputi :

1. Mengidentifikasi permasalahan yang ada serta mengetahui cara menempatkan metode DEA dan Fuzzy Logic sebagai pengukuran efisiensi.

2. Melakukan studi pustaka yang berkaitan dengan penelitian, yang didalamnya dijelaskan mengenai studi efisiensi, studi dari Data Envelopment Analysis (DEA) dan Fuzzy Logic.

3. Melakukan pengumpulan data penelitian (input dan output).

4. Perhitungan terkait ukuran efisiensi sistem biaya entertainment di PT LLL dengan menggunaka metode Data Envelopment Analysis (DEA) dan Fuzzy Logic.

5. Melakukan beberapa perbaikan ataupun kombinsi dengan aplikasi lain atas hasil perhitungan yang telah diperoleh.

6. Membuat kesimpulan penelitian sebagai salah satu masukan untuk pihak perusahaan guna perbaikan maupun pemilihan sistem biaya entertainment yang mestinya diterapkan di PT LLL.

\section{Hasil dan Pembahasan}

Terdapat 5 varian data untuk setiap DMU yang telah terverifikasi. Data tersebut memuat data input dan output, dimana untuk faktor input diwakilkan dengan notasi "X" dan faktor output dinotasikan dengan "Y".

Tabel 2. Model Data Envelopment Analysis Setiap DMU

\begin{tabular}{|c|c|c|c|c|c|}
\hline DMU & $\mathrm{X}_{1}$ & $\mathrm{Y}_{1}$ & $\mathrm{Y}_{2}$ & $\mathrm{Y}_{3}$ & $\mathrm{Y}_{4}$ \\
\hline $\begin{array}{c}1 \\
\text { (Per Penjualan) } \\
\end{array}$ & 5.261 .484 .654 & 9.839 .939 .088 & 277.740 .000 & 7.338 .661 .035 & 4.801.864.597 \\
\hline $\begin{array}{c}2 \\
\text { (Target Penjualan) }\end{array}$ & 10.721 .119 .821 & 10.526 .940 .570 & 266.510 .000 & 12.051 .480 .355 & 11.383 .070 .999 \\
\hline $\begin{array}{c}3 \\
\text { (Operasi Wilayah) }\end{array}$ & 6.836 .092 .071 & 10.036 .861 .274 & 654.394 .000 & 8.244 .510 .836 & 9.191 .167 .570 \\
\hline \multicolumn{6}{|c|}{ Tabel 2. Model Data Envelopment Analysis Setiap DMU Lanjutan } \\
\hline $\begin{array}{c}4 \\
\text { (BUMN Goals) }\end{array}$ & 7.903.723.399 & 71 & 00 & 85.000 & 6.857 .811 .400 \\
\hline $\begin{array}{c}5 \\
\text { (Golden Project) } \\
\end{array}$ & 5.449 .498 .428 & 10.213 .118 .919 & 748.807 .000 & 6.621 .963 .519 & 8.988 .042 .102 \\
\hline
\end{tabular}

\section{Keterangan :}

X1 merupakan nilai input dari total harga pembelian produk.

Y1 merupakan nilai output dari total penjualan produk.

Y2 merupakan nilai output dari total biaya entertainment.

Y3 merupakan nilai output dari total pengiriman produk.

Y4 merupakan niali output dari total receipt pembayaran.

\section{A. Tingkat Efisiensi Performa Sistem}

Proses perhitungan model DEA-CCR dari setiap DMU yang telah dinotasikan, menggunakan sebuat alat perhitungan matematis yaitu software Linggo 11.0. 


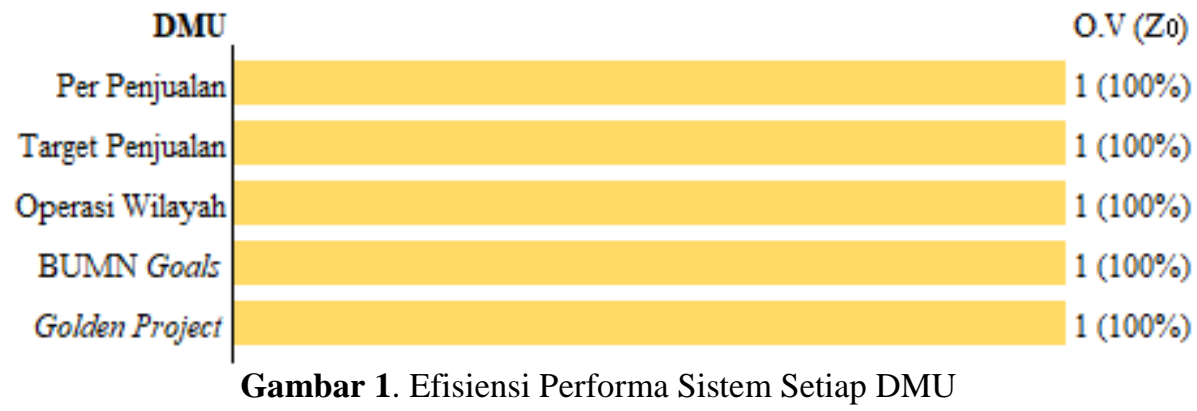

DMU yang memiliki nilai $\mathrm{Z}_{0}=1$ (Objective Value $=1$ ), maka DMU tersebut termasuk dalam kategori DMU yang efficient dan sedangkan sebaliknya, jika DMU memiliki nilai $\mathrm{Z}_{0}<1$ (Objective Value $<1$ ), maka DMU tersebut termasuk dalam kategori DMU yang inefficient. Berdasarkan hasil yang di peroleh dari pengolahan data, maka DMU 1, DMU 2, DMU 3, DMU 4, dan DMU 5 merupakan DMU yang efisien. Sehingga dengan ini akan dilanjutkan dengan perangkingan menggunakan Fuzzy Linier Programming (FLP).

\section{B. Perangkingan Sistem}

Dari hasil pengolahan ke-5 DMU tersebut menggunakan Fuzzy Linier Programming (FLP), akan terlihat posisi dari setiap DMU untuk ukuran dari yang terbesar sampai dengan terkecil setelah proses rekapitulasi dilakukan.

Tabel 3. Rekapitulasi P0 (Margin) Fuzzy Linier Programming

\begin{tabular}{clrrr}
\hline \multirow{2}{*}{ DMU } & \multirow{2}{*}{ Sistem Biaya Entertainment } & \multicolumn{2}{c}{$\mathbf{Z}_{\mathbf{0}}$} & \multirow{2}{*}{$\mathbf{P}_{\mathbf{0}}$ (Margin) } \\
\cline { 3 - 5 } & & $\mathbf{T = 0}$ & $\mathbf{T}=\mathbf{1}$ & \multicolumn{1}{c}{$\mathbf{T}_{\mathbf{0}}$} \\
\hline 1 & Presentase per penjualan & 9.843 .377 .977 & 9.841 .422 .803 & 1.955 .174 \\
\hline 2 & Pertarget penjualan & 11.177 .049 .250 & 11.184 .228 .928 & 7.179 .678 \\
\hline 3 & Operasi wilayah & 11.745 .050 .779 & 11.749 .759 .840 & 4.709 .061 \\
\hline 4 & BUMN goals & 5.625 .915 .723 & 5.626 .501 .094 & 585.371 \\
\hline 5 & Golden project & 10.213 .155 .449 & 10.221 .244 .113 & 8.088 .664 \\
\hline
\end{tabular}

Diketahui jika urutan dari setiap DMU terkait dengan total penjualan maksimal mulai dari yang terbesar ke yang terkecil. Adapun yang pertama yaitu apabila dilihat dari $\mathrm{T}=0$, maka urutannya menjadi DMU 3, DMU 2, DMU, 5, DMU 1, dan DMU 4 (artinya pengasumsian batas toleransi diabaikan) dimana untuk DMU 3 memiliki total penjualan sebesar 11.745.050.779 sebagai total penjualan terbesar dan DMU 4 dengan total penjualan 5.625.915.723 sebagai total penjualan terendah pada periode ini dalam kurun waktu 2 tahun yaitu 2017 sampai dengan 2018. Sedangkan dengan asumsi batas toleransi yang diperbolehkan, maka posisi besaran total penjualan setiap DMU juga ikut mengalami perubahan.

\section{Tingkat Preferensi Pengambil Keputusan}

Setiap pengambil keputusan memiliki masing-masing preferensi terhadap sistem yang telah berjalan. Pada tahap ini akan diketahui besaran kekonsistenan para pemangku jabatan terkait dengan pemberian biaya tersebut. Preferensi akan ditranformasikan kedalam model matematis yaitu dengan membentuk sebuah matriks. Notasi yang digunakan untuk merepresentasikan preferensi pengambil keputusan pertama adalah $\mathrm{P}^{1}$ dan preferensi pengambil keputusan kedua adalah $\mathrm{P}^{2}$.

$\mathrm{P}^{1}=\left[\begin{array}{ccccc}0,5 & 0,3 & 0,7 & 0,1 & 0,5 \\ 0,7 & 0,5 & 0,6 & 0,6 & 0,6 \\ 0,3 & 0,4 & 0,5 & 0,2 & 0,8 \\ 0,9 & 0,4 & 0,8 & 0,5 & 0,7 \\ 0,8 & 0,5 & 0,7 & 0,6 & 0,3\end{array}\right]$

Dan,

$\mathrm{P}^{2}=\left[\begin{array}{lllll}0,5 & 0,4 & 0,6 & 0,2 & 0,8 \\ 0,6 & 0,5 & 0,7 & 0,4 & 0,3 \\ 0,4 & 0,3 & 0,5 & 0,1 & 0,1 \\ 0,8 & 0,6 & 0,9 & 0,5 & 0,2 \\ 0,9 & 0,4 & 0,8 & 0,5 & 0,4\end{array}\right]$ 
Nilai relasi preferensi fuzzy yang konsisten dari pengambil keputusan akan dicari dan hasil tersebut akan dinotasikan masing-masing sebagai $\widehat{\mathrm{P}}^{1}$ maupun $\widehat{\mathrm{P}}^{2}$. Hasil yang diperoleh untuk preferensi pengambil keputusan yang pertama $\left(\mathrm{P}^{1}\right)$ yaitu 0,18 dan preferensi pengambil keputusan yang kedua $\left(\mathrm{P}^{2}\right)$ yaitu 0,03 . Artinya preferensi pengambil keputusan yang pertama $\left(\mathrm{P}^{1}\right)$ memiliki nilai yang lebih mendekati dengan nilai 1 dibandingkan dengan preferensi pengambil keputusan yang kedua $\left(\mathrm{P}^{2}\right)$, sehingga dapat dikatakan jika preferensi pengambil keputusan yang pertama $\left(\mathrm{P}^{1}\right)$ lebih konsisten atas pernyataan yang diajukan tentunya terkait dengan sistem pemberian biaya entertainment.

\section{KESIMPULAN}

Pengukuran sistem pemberian biaya entertainment menggunakan metode DEA-CRS terhadap DMU yang terklasifikasi, diantaranya yaitu Sistem Presentase Perpenjualan (DMU1), Sistem Pertarget Penjualan (DMU2), Sistem Operasi Wilayah (DMU3), Sistem BUMN Goals (DMU4), dan Sistem Golden Project (DMU5) memiliki nilai efisiensi $Z_{0}$ (Objective Value) masing-masing sebesar 1 yang artinya dari kesemua sistem yang teruji bersifat efisien. Perankingan dengan pendekatan Fuzzy Linier Programing (FLP) menunjukan bahwa jika berorientasi atas kapasitas total penjualan yang optimum, maka diperoleh urutan yaitu Sistem Operasi Wilayah (DMU3) diperingkat pertama dengan total penjualan sebesar Rp.11.745.050.779, diikuti dengan Sistem Pertarget Penjualan (DMU2) diposisi kedua dengan total penjualan sebesar Rp.11.177.049.250, kemudian Sistem Golden Project (DMU5) diperingkat ketiga dengan total penjualan sebesar Rp.10.213.155.449, dengan Sistem Presentase Perpenjualan (DMU1) menempati tempat keempat dengan total penjualan sebesar Rp.9.843.377.977, dan Sistem BUMN Goals (DMU4) di posisi terakhir dengan total penjualan sebesar Rp. 5.625.915.723. Dengan C-IOWA diperoleh nilai Consistency Index (CI) P1 > P2 yaitu nilai preferensi ke-1 sebesar 0,18 dan nilai preferensi ke-2 sebesar 0,03 artinya preferensi pertama lebih konsisten dibandingkan dengan preferensi kedua yang mengharapkan sistem pemberian biaya entertainment dapat terus berlangsung.

\section{UCAPAN TERIMA KASIH}

Penelitian ini disusun tentunya tidak lepas dari beberapa bantuan serta motivasi dari semua pihak, maka dari itu disini penulis tidak melupakan jasa mereka yang terlibat dengan menyampaikan rasa terimakasih yang sangat besar. Diantaranya terimakasih kepada :

1. PT LLL Selaku pemberi fasilitas tempat sekaligus obyek penelitian.

2. Kedua orang tua yang selalu menyertakan do'a dan dorongannya di setiap proses penelitian berlangsung.

3. Ibu Nur dan Ibu Anjani yang selalu setia memberikan arahan serta masukan tentunya beliau selaku pembimbing lapangan di PT LLL.

\section{REFERENSI}

[1] Firman Aji Gunawan. (2013). “Analisa Tingkat Efisiensi Bank BUMN Dengan Pendekatan Data Envelopment Analysis (DEA)”, Jurnal Ilmu \& Riset Manajemen, 2(8).

[2] Filardo, A., Negro, N.P. dan Kunaifi, A. (2017). "Penerapan Data Envelopment Analysis dalam Pengukuran Efisiensi Retailer Produk Kendaraan Merek Toyota”, Jurnal Sains dan Seni ITS, 6(1),pp.73-77.

[3] Rasyid, H. A. L. (2012). "Pemeringkatan Dan Pengukuran Efisiensi Supplier Berdasarkan Green Purchasing Dengan Metode Analytical Network Procces Dan Data Envelopment Analysis", Program Studi Teknik Industri, Fakultas Teknik, Universitas Indonesia.

[4] Susilaningrum D, W., Kuswanto, H. dan Suliasih, W.. (2013). "Penerapan Data Envelopment Analysis Untuk Efisiensi Kinerja Karyawan Pada PT X”; Jurnal Sains dan Seni ITS.

[5] Kusumadewi, Sri, dan Hari Purnomo. 2004. “Aplikasi Logika Fuzzy Untuk Pendukung Keputusan”. Yogyakarta: Graha Ilmu.

[6] Kusumadewi, S., Hartati, S., Harjoko, A., dan Retantya Wardoyo. 2006. "Fuzzy Multi-Attribute Decision Making”. Yogyakarta: Graha Ilmu. 